\title{
Siblings with ACTH Insensitivity Due to Lack of ACTH Binding to the Receptor
}

\author{
YuKIYO YAMAMOTO, YASUSADA KAWADA, MASANORI NODA, \\ MINORU YAMAGISHI, OSAMU ISHIDA*, TAKASHI FUJIHIRA*, \\ FUMIHIKO SHIRAKAWA*, AND ISAO MORIMOTO* \\ Department of Pediatrics, *First Department of Internal Medicine, \\ University of Occupational and Environmental Health, Kitakyushu 807, Japan
}

\begin{abstract}
We report two siblings, a 9-year-old boy and 4-year-old girl, with ACTH insensitivity. They were referred to our hospital because of pigmentation of the skin. They had normal plasma cortisol and urinary 17-OHCS levels despite markedly high plasma $\mathrm{ACTH}$, and these did not respond to consecutive 3-day ACTH-Z administration, but plasma aldosterone responded normally to increased plasma renin activity after a low sodium diet. We examined the characteristics of ACTH receptors in peripheral blood mononuclear leukocytes (MNLs) obtained from the patients and their family. Adenylate cyclase generation caused by an addition of ACTH did not occur in MNLs from the patients. In studies on ACTH binding to MNLs, a lack of high-affinity ACTH binding was observed in the patients. These results suggest that the patients have a defect in ACTH binding to the receptors, resulting in ACTH insensitivity. The reason for this defect in ACTH binding remains unclear because no significant mutation in the $\mathrm{ACTH}$ receptor DNA sequence was detected in the MNLs of these patients.
\end{abstract}

Key words: ACTH, ACTH insensitivity, ACTH receptor, Cyclic AMP, Binding study

(Endocrine Journal 42: 171-177, 1995)

ACTH insensitivity, which was first described as familial Addison's disease by Shepard et al. [1], is primary adrenal insufficiency characterized by normal mineralocorticoid synthesis, but a lack of steroidogenic response to endogenous and exogenous ACTH (1-24) stimulation. Smith et al. [2] have demonstrated that peripheral blood mononuclear lymphocytes (MNLs) possess ACTH receptors similar to adrenocortical cells and a lack of high-affinity ACTH binding was observed in MNLs from a patient with ACTH insensitivity syndrome. Yamaoka et al. [3] reported hereditary cases where the defect lies in the intracellular signaling pathway distal to

Received: July 19, 1994

Accepted: November 18, 1994

Correspondence to : Yukiyo YAMAMOTO, Department of Pediatrics, University of Occupational and Environmental Health, 1-1 Iseigaoka, Yahatanishi-ku, Kitakyushu 807, Japan the ACTH receptor (postreceptor defect). Recently ACTH receptor, that consists of single exon, was cloned [4].

In this report, we describe two siblings, a 9-yearold boy and a 4-year-old girl, with isolated glucocorticoid deficiency due to ACTH insensitivity, and who have a defect in ACTH binding to the receptor. We also investigated ACTH receptor gene in this family.

\section{Case Reports}

Case 1

A 9-year-old boy was referred to our hospital because of pigmentation of the skin. He was born after a normal pregnancy and delivery. Birth weight was $2700 \mathrm{~g}$. He had skin pigmentation and several episodes of vomiting soon after his birth. 
On admission, his height was $134.7 \mathrm{~cm}(+0.7 \mathrm{SD})$ and weight, $27 \mathrm{~kg}$. His bone age was 13.8 years (TW2 method), and blood pressure was $94 / 40$ $\mathrm{mmHg}$. His skin was generally dark brown, but his external genitalia were normal. His sexual development was stage I (Tanner Stage).

His blood cell count was normal, serum sodium $139 \mathrm{mmol} / \mathrm{L}$, potassium $3.5 \mathrm{mmol} / \mathrm{L}$, chloride 102 $\mathrm{mmol} / \mathrm{L}$, and fasting blood glucose was 3.83 $\mathrm{mmol} / \mathrm{L}$. Hormonal data are shown in Table 1. Despite greatly increased plasma ACTH; he had normal plasma cortisol and urinary 17-hydroxycorticosteroids (17-OHCS), and low plasma dehydroepiandrosterone (DHEA), and urinary 17ketosteroids (17-KS). However, plasma renin activity (PRA) and aldosterone were normal on a regular diet. An iv bolus injection of corticotropin releasing hormone (human $\mathrm{CRH}$; $100 \mu \mathrm{g}$, provided by Dr. T. Tanaka of Teikyo Univ.) induced a slight response in plasma ACTH $(376 \rightarrow 469 \mathrm{pmol} / \mathrm{L}$ at 15 $\mathrm{min})$, but the plasma cortisol did not respond. Plasma cortisol and urinary 17-OHCS and 17-KS did not respond to a consecutive 3-day intramuscular injection of 1-24 ACTH-Z (0.5 mg; Daiichi Pharmaceutical Co., Tokyo, Japan), but the plasma aldosterone concentration increased normally after a 3-day low sodium ( $3 \mathrm{~g} /$ day) diet. Thyroid function was normal (Triiodothyronine $1.46 \mathrm{nmol} /$ $\mathrm{L}$, Thyroxine $89 \mathrm{nmol} / \mathrm{L})$. The response of plasma TSH to the TRH ( $200 \mu \mathrm{g}$; TANABE SEIYAKU Co., Ltd, Osaka, Japan) was normal $(0.47 \rightarrow 8.3 \mathrm{mU} / \mathrm{L}$ at $60 \mathrm{~min})$. The response of plasma GH observed after the administration of regular insulin (Humalin R: 2.5 U; Eli Lilly and Company, Indianapolis, USA) was normal $(0.2 \rightarrow 13.0 \mu \mathrm{g} / \mathrm{L}$ at $60 \mathrm{~min})$. The responses of plasma LH and FSH to GnRH ( $60 \mu \mathrm{g}$; TANABE SEIYAKU Co., Ltd) were reasonable for his age $(\mathrm{LH},<0.1 \rightarrow 1.6$ at $30 \mathrm{~min} ; \mathrm{FSH},<0.3 \rightarrow 3.6$ $\mathrm{IU} / \mathrm{L}$ at $60 \mathrm{~min}$ ). Antibodies to adrenocortical cells were negative (Indirect fluorescent antibody test, BML, Tokyo, Japan).

\section{Case 2}

A 4-year-old girl (the younger sister of case 1) was also born after a normal pregnancy and delivery. Her birth weight was $3110 \mathrm{~g}$. She had skin pigmentation soon after her birth and frequent vomiting when she was feverish. But no hypoglycemia was seen on blood examination. On admission, her height was $114.1 \mathrm{~cm}(+2.8 \mathrm{SD})$ and
Table 1. Basal hormone levels in case 1 and 2

\begin{tabular}{llcc}
\hline & Normal range* & Case 1 & Case 2 \\
\hline Plasma & & & \\
ACTH & $(1-11 \mathrm{pmol} / \mathrm{L})$ & 262.1 & 171.4 \\
Cortisol & $(120-550 \mathrm{nmol} / \mathrm{L})$ & 209.7 & 234.5 \\
DHEA & $(3.5-10.4 \mathrm{nmol} / \mathrm{L})$ & 1.38 & 1.38 \\
Testosterone & $(0.06-0.4 \mathrm{nmol} / \mathrm{L})$ & $<0.18$ & $<0.18$ \\
Aldosterone & $(140-450 \mathrm{pmol} / \mathrm{L})$ & 257.5 & 193.9 \\
Renin activity & $(0.15-0.6 \mathrm{ng} / \mathrm{L} / \mathrm{s})$ & 0.56 & 0.64 \\
Urine & & & \\
17-OHCS & $(2.8-15.5 \mu \mathrm{mol} / \mathrm{d})$ & 12.1 & 9.1 \\
17-KS & $(3.5-14 \mu \mathrm{mol} / \mathrm{d})$ & 1.39 & 0.66 \\
\hline
\end{tabular}

*Normal range in children. DHEA, dehydroepiandrosterone; 17-OHCS, 17-hydroxycorticosteroids; 17-KS, 17-ketosteroids.

weight, $19.0 \mathrm{~kg}$. Her bone age was 7.7 years (TW2 method), and blood pressure was $92 / 50 \mathrm{mmHg}$. The color of her general skin was dark brown but external genitalia were normal. Her sexual development was stage I (Tanner Stage).

She also had normal levels of serum electrolytes (sodium, 140; potassium, $3.6 \mathrm{mmol} / \mathrm{L}$ ) and glucose $(4.27 \mathrm{mmol} / \mathrm{L})$ in the blood. Her hormonal data were very similar to those observed in her brother. She had normal plasma cortisol and urinary 17OHCS, and low plasma DHEA and urinary 17-KS in spite of a considerable increase in plasma ACTH. The plasma cortisol and urinary 17-OHCS and 17KS did not increase following a 3-day administration of ACTH-Z, but her plasma aldosterone was normal and responded after a low sodium diet for 3 days. Thyroid function was normal (Triiodothyronine, $1.0 \mathrm{nmol} / \mathrm{L}$; Thyroxine, 63 $\mathrm{nmol} / \mathrm{L})$. The response of plasma TSH to TRH $(150 \mu \mathrm{g})$ was normal $(1.1 \rightarrow 9.5 \mathrm{mU} / \mathrm{L}$ at $60 \mathrm{~min})$. The response of plasma GH to insulin tolerance test was normal $(3.4 \rightarrow 21.7 \mu \mathrm{g} / \mathrm{L}$ at $60 \mathrm{~min})$. Gonadotropin responses to GnRH (50 $\mu \mathrm{g})$ stimulation were normal for her age ( $\mathrm{LH},<0.1 \rightarrow 3.0$ at $30 \mathrm{~min}$; $\mathrm{FSH}, 0.8 \rightarrow 9.9 \mathrm{IU} / \mathrm{L}$ at $60 \mathrm{~min}$ ). She also did not have antibodies to cells.

\section{Methods}

\section{Cyclic AMP (cAMP) generation in MNLs}

MNLs were isolated from peripheral blood with a lymphocyte separation medium (Litton Bionetics, Kensington, MD, USA), sedimentation at 1600 
rpm for $30 \mathrm{~min}$ at room temperature as described by us [5]. The cells were washed three times with phosphate buffer saline (PBS) and were resuspended in a RPMI 1640 medium (Nissui Pharmaceutical Co., Tokyo, Japan) containing $10 \%$ fetal calf serum (FBS: Hyclone Laboratories, Inc., Logan, UT, USA). $1 \times 10^{6}$ cells of the medium in a microfuge tube (Eppendorf, Hamburg, Germany) were incubated with $10 \mu \mathrm{M}$ of forskolin (Sigma, St Louis, MO, USA) and 1 and $10 \mathrm{ng} / \mathrm{mL}$ of ACTH (Sigma) for $15 \mathrm{~min}$ at $37^{\circ} \mathrm{C}$. The cells were then washed three times with PBS and lysed by freezing and thawing several times. After centrifugation at $3000 \mathrm{rpm}$ for 15 min at $4{ }^{\circ} \mathrm{C}$, cAMP content in the supernatant was measured with a RIA kit (Yamasa Co., Chiba, Japan) and corrected for the protein content determined with a protein assay kit (Bio Rad, Richmond, CA, USA).

\section{Binding assay of ${ }^{125} \mathrm{I}-\mathrm{ACTH}$}

MNLs were isolated from the peripheral blood of the patients, a healthy sister, parents and a healthy volunteer by the above method. The peripheral blood of the patients was obtained 3 days after withdrawal of the steroid regimen. We obtained informed consent from their parents. A binding assay was performed by a modified method, which was described previously by us [6]. The cells were washed several times with ice-cold Krebs-Riger carbonate buffer containing $0.5 \%$ human albumin and $0.2 \%$ glucose and adjusted to $1 \times$ $10^{6}$ cells $/ 0.1 \mathrm{ml}$ buffer. Different doses of ${ }^{125} \mathrm{I}-$ ACTH (SA:- $2000 \mathrm{Ci} / \mathrm{mol}$; Amershan, Buckinghampshire, England) were added to the cell suspension in Eppendorf microfuge tubes. After incubation at $4{ }^{\circ} \mathrm{C}$ for $20 \mathrm{~min}$, a $300 \mu \mathrm{l}$ of mixture $20 \%$ olive oil and $80 \%$ Di-N-butyl phthalate was added and then centrifuged for $1 \mathrm{~min}$ in an Eppendorf centrifuge. The radioactivity bound to the cells and in the supernatants was counted with a gamma counter. The nonspecific binding of ACTH was estimated in the presence of 100-fold excess of cold ACTH. The results (specific binding) were expressed as the mean for duplicate samples from which nonspecific binding was subtracted.

\section{Sequencing of ACTH-receptor}

Leukocyte genomic DNA was prepared from whole blood and analyzed by polymerase chain reaction (PCR) with the following primer pairs: 6835 (5'-CAAGGATCCGTGAATTCAAGTCCAAGTAA-3') 1597AS (5'-ATTCTCGAGAATTCTAA-

Table 2. Hormone levels after an ACTH-Z stimulation and a low sodium diet

\begin{tabular}{|c|c|c|c|c|c|}
\hline \multicolumn{6}{|c|}{ i) 3-day ACTH-Z (0.5 mg) stimulation } \\
\hline & \multirow[b]{2}{*}{ Normal range* $^{*}$} & \multicolumn{2}{|c|}{ Case 1} & \multicolumn{2}{|c|}{ Case 2} \\
\hline & & Day 0 & Day 4 & Day 0 & Day 4 \\
\hline \multicolumn{6}{|l|}{ Plasma } \\
\hline Cortisol & $(120-550 \mathrm{nmol} / \mathrm{L})$ & 209.7 & 226.2 & 234.5 & 248.3 \\
\hline \multicolumn{6}{|l|}{ Urine } \\
\hline $17-\mathrm{OHCS}$ & (2.8-15.5 $\mu \mathrm{mol} /$ day) & 12.1 & 14.9 & 9.1 & 6.4 \\
\hline $17-\mathrm{KS}$ & (3.5-14 $\mu \mathrm{mol} / \mathrm{day})$ & 1.38 & 2.01 & 0.66 & 0.42 \\
\hline \multicolumn{6}{|c|}{ ii) PRA and plasma aldosterone levels on a 3-day low sodium ( $3 \mathrm{~g}$ ) diet } \\
\hline & & \multicolumn{2}{|c|}{ Case 1} & \multicolumn{2}{|c|}{ Case 2} \\
\hline & & Day 0 & Day 4 & Day 0 & Day 4 \\
\hline \multicolumn{6}{|l|}{ Plasma } \\
\hline Renin activity & $(0.15-0.6 \mathrm{ng} / \mathrm{L} / \mathrm{s})$ & 0.69 & 1.30 & 0.72 & 1.36 \\
\hline Aldosterone & $(140-450 \mathrm{pmol} / \mathrm{L})$ & 446.0 & 2147.1 & 336.4 & 1092.7 \\
\hline \multicolumn{6}{|l|}{ Urine } \\
\hline $\mathrm{Na}$ & (<70 mmol/day) & 45.6 & 2.6 & 34.2 & 7.6 \\
\hline
\end{tabular}

* Normal range in children. Abbereviations, see Table 1. 
AACGAGGG-3'), which amplify a whole cDNA region ACTH-receptor. Because recently Mountjoy et al. [4] reported ACTH receptor gene, that consists of single exon. PCR was 30 cycles at $94^{\circ} \mathrm{C}$ for $30 \mathrm{sec}, 47^{\circ} \mathrm{C}$ for $1 \mathrm{~min}$, and $72{ }^{\circ} \mathrm{C}$ for $1 \mathrm{~min}$ in a $50 \mu \mathrm{L}$ volume with Taq polymerase (WAKO, Osaka, Japan). The PCR products were analyzed by agarose gel electrophoresis, and subcloned in vector pCR1000 (Invitrogen, San Diego, CA, USA). After analysis of transformants, appropriate plasmids were prepared. Six clones were sequenced by the dideoxy chain termination technique with AmpliTaq $^{\mathrm{TM}}$ DNA polymerase (Applied Biochesystems, Foster City, CA, USA), with a autosequencer 373A (Applied Biochesystems). All sequence data were checked by the INHERIT ${ }^{\mathrm{TM}}$ system (Applied Biochesystems) to detect point mutation.

\section{Results}

\section{cAMP generation by ACTH in mononuclear leukocyte (MNLs)}

To elucidate ACTH insensitivity in the patients, we measured the cAMP concentration in cultured MNLs obtained from the patients and their family. Forskolin $(10 \mu \mathrm{M})$ stimulated an increase in the intracellular level of cAMP in MNLs from the pa-

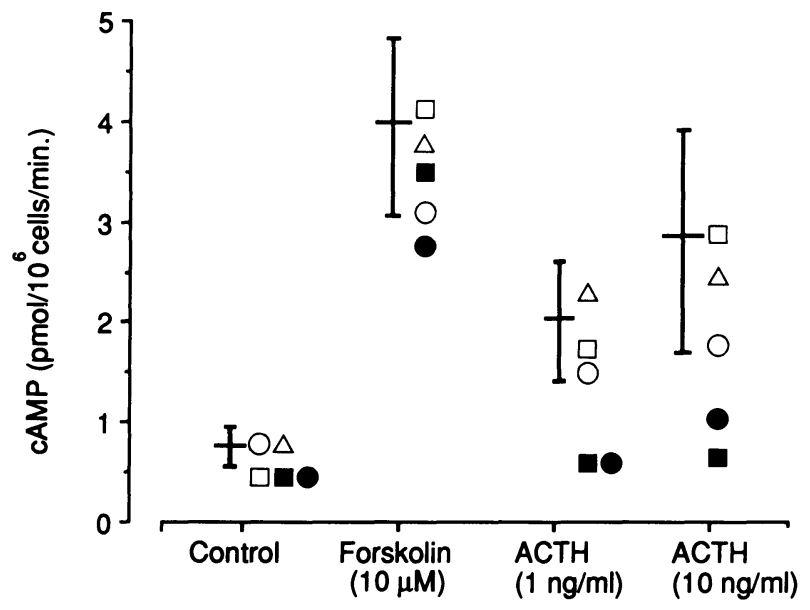

Fig. 1. Cyclic AMP (cAMP) generation to ACTH. Basal cAMP accumulation and its generation to forskolin $(10 \mu \mathrm{M})$ and $\mathrm{ACTH}(1,10 \mathrm{ng} / \mathrm{mL})$ in mononuclear lymphocytes (MNLs) from the patients (case $1 \mathbf{0}$, case 20 ), a healthy sister $(\triangle)$, parents (father $\square$, mother $\bigcirc$ ), and five normal volunteers. Results obtained from normal volunteers represent the mean \pm SD. tients, a healthy sister, their parents and normal controls and there was no difference among them (Fig. 1). ACTH (1 and $10 \mathrm{ng} / \mathrm{mL}$ ) dose-dependently stimulated cAMP accumulation in MNLs from the healthy sister and parents to the range for normal volunteers (Fig. 1). However, cAMP generation in MNLs from the patients was not increased by the addition of ACTH at a concentration of either $1 \mathrm{ng} / \mathrm{mL}$ or $10 \mathrm{ng} / \mathrm{mL}$.

\section{Binding assay of ${ }^{125} \mathrm{I}-\mathrm{ACTH}$ to $\mathrm{MNLS}$}

Only $2-3 \%$ of ${ }^{125} \mathrm{I}$-labelled ACTH analogue was bound to lymphocytes from normal controls, and $20-30 \%$ of the bound radioactivity displaced a $10-$ fold excess of cold ACTH (1-24). The results of Scatchard analysis of ${ }^{125} \mathrm{I}$-ACTH binding to MNLs from the patients, their family and a normal volunteer are shown in Fig. 2. There were two binding sites, a high-affinity binding site $(\mathrm{Kd}, 0.31-0.34 \mathrm{nM}$; number of receptors, 693-754/cell) and a low-affinity binding site $(\mathrm{Kd}, 2.47-2.68 \mathrm{nM}$; number of receptors, 4100-5065/cell) in MNLs from the normal volunteers, healthy sister and parents. However MNLs from patients lacked a high-affinity ACTH binding site (Fig. 2) and had only a low-affinity binding site (Kd: case 1, $2.05 \mathrm{nM}$; case 2, $2.10 \mathrm{nM}$; number of receptors: 2653/cell, 2533/ cell, respectively).

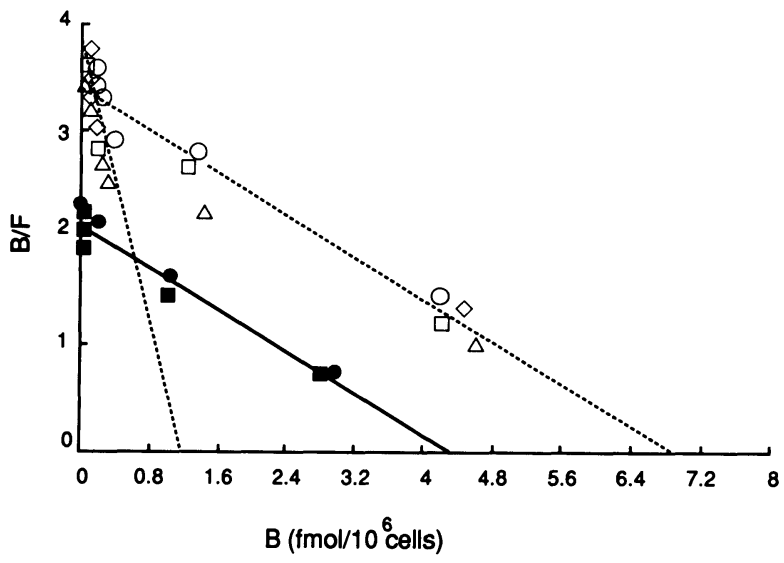

Fig. 2. Scatchard analysis of ${ }^{125} \mathrm{I}-\mathrm{ACTH}$ binding to MNLs. MNLs were isolated from peripheral blood from the patients (case $1 \mathbf{\square}$, case $2 \bullet$ ), a healthy sister $(\Delta)$, parents (father $\diamond$, mother $\bigcirc$ ), and a healthy volunteer $(\square)$. In the healthy sister, parents, and healthy volunteer, there were two binding sites, a high-affinity and a low-affinity (dashed line). The patients had only a low-affinity binding site (line). 


\section{Gene analysis}

We investigated the ACTH-receptor DNA sequence in our patients, their parents, and healthy sister by polymerase chain reaction amplification of DNA with pairs of primers that span the ACTHreceptor domain, but we did not find any significant mutation in them.

\section{Discussion}

Physical findings and hormonal studies indicated that our cases had isolated glucocorticoid deficiency due to ACTH insensitivity. There are several cases in which height growth and bone age were accelerated and it was suggested that excessive adrenal-androgen is a factor in these symptoms [7-11]. The bone age of our patients also accelerated, but the adrenal-androgen concentration was low and the responses to LH-RH were normal for age. We cannot explain why the bone age accelerated.

Lefkowitz et al. [12] first reported that there are two binding sites to ACTH in mouse adrenal tumor cells. Two ACTH binding sites were also observed in isolated rat adrenocortical cells [13, 14]. On the other hand, Buckley and Ramachandran [15] indicated that there is only one ACTH binding site in rat adrenocortical cells. It is unclear whether ACTH receptor has one or two binding sites on adrenocortical cells. Smith et al. [2] reported that two binding sites, a high-affinity and a low-affinity site, exist on human MNLs, and suggested a correlation between the structure or expression of ACTH receptors on MNLs and adrenocortical cells. They also studied ACTH binding to MNLs obtained from a patient with ACTH insensitivity syndrome and found that there were no high-affinity ACTH binding sites on the MNLs, suggesting the abnormalities in the receptor sequence, receptor synthesis or receptor expression. In our analysis of ACTH binding to MNLs, our patients lacked the high-affinity ACTH binding site, that existed in MNLs from a healthy sister, their parents and a normal control. It is therefore certain that our patients have a defect in ACTH binding to the receptors.

Moore et al. [16] reported that ACTH does not increase adenylate cyclase activity even in MNLs from normal subjects, and suggested that true ACTH receptors are not expressed on peripheral lymphocytes. Leukocytes might express one of the MSH receptors, which will also respond to ACTH. But results of studies on ACTH-binding and CAMP generation in MNLS from our patients were quite different from those for their parents, the normal sibling and control. Our patients have remarkable skin pigmentation, suggesting that their MSH receptor is not abnormal. These findings suggest that the defect of ACTH binding in MNLs from the patients is due to a defect of binding to "ACTH" receptor, and ACTH insensitivity in our patients is caused by a defect in ACTH binding to adrenocortical cells. Yamaoka et al. [3] reported two patients with ACTH insensitivity syndrome whose ACTH receptors on MNLs were similar to normal controls in the results of Scatchard analysis of ACTH binding and ACTH stimulated cAMP generation. Furthermore, the in vivo infusion of dibutyryl cAMP did not cause normal steroidogenic responses in the two patients. They therefore concluded that the defect appears to be distal to cAMP formation.

A previous study demonstrated that at physiological concentrations $\left(10^{-8}, 10^{-9} \mathrm{M}\right) \mathrm{ACTH}$ induced a positive trophic effect on both ACTH binding and cAMP response in adrenocortical cells, as compared with no addition of ACTH [17]. MNLs used in our in vitro studies were obtained after the withdrawal of hydrocortisone administration, but their ACTH levels were normal (case 1: ACTH, 26.4 pmol/L; cortisol, $126 \mathrm{nmol} / \mathrm{L}$; case 2: ACTH, 36.8 $\mathrm{pmol} / \mathrm{L}$; cortisol l, $115 \mathrm{mmol} / \mathrm{L}$ ). It appears that the results of our in vitro studies are not based on the desensitization of ACTH receptors caused by endogenous ACTH.

In studies on MSH-receptor, Mountjoy et al. [4] revealed that there are four subtypes for melanocortine receptor (MC-R). They also suggest that among MC-Rs, MC2-R is an ACTH-receptor, resulting from localization in which MC2-R mRNA is expressed in adrenal tissue, primarily across the zona fasciculata. ACTH receptor, which consists of single exon and contains no intron in the coding, was cloned. Clark et al. [18] reported a patient with ACTH insensitivity who had a single base mutation of ACTH receptor gene, resulting in a change in codon 74 from serine to isoleucine, in the sequence coding for the second transmembrane domain of ACTH receptor. But no further expression study has been done. On the other hand, 
Naville et al. [19] reported five different families with ACTH insensitivity who did not have any mutation in the ACTH receptor gene. Takayanagi et al. [20] also reported that no mutation was detected in ACTH-receptor DNA sequence of five Japanese patients. They concluded that a defect in the intracellular signaling pathway distal to ACTHreceptor may be involved in these cases. In our analysis of the ACTH-receptor DNA sequence, we did not find any significant mutation. But the results of our in vitro studies indicate that no post receptor defect is present in our patients. An ACTH-receptor other than MR-2 may therefore exist. ACTH binds to the receptor that couples to guanine-nucleotide-binding-proteins (G-proteins) and activates adenylate cyclase [17, 21, 22]. A defect in this protein is reported in patients with pseudohypoparathyroidism (PHP), which is characterized by reduced expression or function of the $\alpha$ subunit of the stimulatory G-protein $(\mathrm{Gs} \alpha)$ in the action of parathyroid and other hormones that use cyclic AMP as an intracellular second messenger. A defect in the G-protein could cause multiple hormone resistance in patients with PHP [23-28]. Because of the hormonal data and CAMP response in our patients, it seems that they do not have a defect in the G-proteins. Further studies will be necessary to elucidate the exact pathogenesis of ACTH insensitivity in our cases.

\section{References}

1. Shepard TH, Landing BH, Mason DG (1959) Familial Addison's disease: case reports of two sisters with corticoid deficiency unassociated with hypoaldosteronism. Am J Dis Child 97: 154-162.

2. Smith EM, Brosnan P, Meyer WJ, Blalock JE (1987) An ACTH receptor on human mononuclear leukocytes: relation to adrenal ACTH-receptor activity. N Engl J Med 317: 1266-1269.

3. Yamaoka T, Kudo T, Takuwa Y, Kawakami Y, Itakura M, Yamashita K (1992) Hereditary adrenocortical unresponsiveness to adrenocorticotropin with a postreceptor defect. J Clin Endocrinol Metab 75: $270-274$.

4. Mountjoy KG, Robbins LS, Mortrud MT, Cone RD (1992) The cloning of a family of genes that encode the melanocortin receptors. Science 257: 1248-1251.

5. Shirakawa F, Yamashita U, Chedid M, Mizel SB (1988) Cyclic AMP-an intracellular second messenger for interleukin 1. Proc Natl Acad Sci USA 85: 8201-8205.

6. Shirakawa F, Tanaka Y, Ota T, Suzuki H, Eto S, Yamashita U (1987) Expression of interleukin 1 receptors on human peripheral T cells. J Immunol 138: 4243-4248.

7. Monteleone JA, Monteleone PL (1970) Hereditary adrenocortical unresponsiveness to ACTH-another case. Pediatrics 46: 321-322.

8. Kershnar AK, Roe TF, Kogut MD (1972) Adrenocorticotropic hormone unresponsiveness: report of a girl with excessive growth and review of 16 reported cases. J Pediatr 80: 610-619.

9. Kelch RP, Kaplan SL, Biglieri EG, Daniels GH, Epstein CJ, Grumbach MM (1972) Hereditary adrenocortical unresponsiveness to adrenocorticotropic hormone. J Pediatr 81: 726-736.
10. Moshang Jr T, Rosenfield RL, Bongiovanni AM, Parks JS, Amrhein JA. (1973) Familial glucocorticoid insufficiency. J Pediatr 82: 821-826.

11. Thistlethwaite D, Darling JAB, Fraser R, Mason PA, Rees LH, Harkness RA (1975) Familial glucocorticoid deficiency: studies of diagnosis and pathogenesis. Arch Dis Child 50: 291-297.

12. Lefkowitz RJ, Roth J, William P, Pastan I (1970) ACTH receptors in the adrenal: specific binding of ACTH -125I and its relation to adenyl cyclase. Proc Natl Acad Sci USA 65: 745-752.

13. Wolfsen AR, McIntyre HB, Odell WD (1972) Adrenocorticotropin measurement by competitive binding receptor assay. J Clin Endocrinol Metab 34: 684-689.

14. McIlhinney RAJ, Schulster D (1975) Studies the binding of ${ }^{125} \mathrm{I}$-labelled corticotrophin to isolated rat adrenocortical cells. J Endocrinol 64: 175-184.

15. Buckley DI, Ramachandran J (1981) Characterization of corticotropin receptors on adrenocortical cells. Proc Natl Acad Sci USA 78: 7431-7435.

16. Moore PSJ, Couch RM, Perry YS, Shuckett EP, Winter JSD (1991) Allgrove syndrome: an autosomal recessive syndrome of ACTH insensitivity, achalasia and alacrima. Clin Endocrinol 34: 107-114.

17. Penhoat A, Jaillard C, Saez JM (1989) Corticotropin positively regulates its own receptors and cAMP response in cultured bovine adrenal cells. Proc Natl Acad Sci USA 86: 4978-4981.

18. Clark AJL, Mcloughlin L, Grossman A (1993) Familial glucocorticoid deficiency associated with point mutation in the adrenocorticotropin receptor. Lancet 341: 461-462.

19. Naville D, Chatelain P, Brunelli P, Begeot M (1993) A study of the ACTH receptor gene in five differ- 
ent families with ACTH insensitivity. 75th Annual Meeting of American Endocrine Soc 237 (Abstract).

20. Takayanagi $R$, Sakai $Y$, Nawata H, Nishiyama S, Ito T, Kodama M, Matsuda I, Matsuda H (1993) Adrenocorticotropin receptor in familial glucocorticoid deficiency. Nippon Rinsho 51: 2643-2642 (In Japanese).

21. Rae PA, Gutmann NS, Tsao J, Schimmer BP (1979) Mutations in cyclic AMP-dependent protein kinase and corticotropin (ACTH)-sensitive adenylate cyclase affect adrenal steroidogenesis. Proc Natl Acad Sci USA 76: 1896-1900.

22. John ME, John MC, Boggaram V, Simpson ER, Waterman MR (1986) Transcriptional regulation of steroid hydroxylase genes by corticotropin. Proc Natl Acad Sci USA 83: 4715-4719.

23. Farfel Z, Brickman AS, Kaslow HR, Brothers VM, Bourne HR (1980) Defect of receptor-cyclase coupling protein in pseudohypoparathyroidism. $N$ Engl J Med 303: 237-242.

24. Mallet E, Carayon P, Amr S, Brunelle P, Ducastelle T, Basuyau JP, Menibus CH (1982) Coupling defect of thyrotropin receptor and adenylate cyclase in a pseudohypoparathyroid patient. J Clin Endocrinol Metab 54: 1028-1032.
25. Farefel Z, Abood ME, Brickman AS, Bourne HR (1982) Deficient activity of receptor-cyclase coupling protein in transformed lymphoblast of patients with pseudohypoparathyroidism, type I. J Clin Endocrinol Metab 55: 113-117.

26. Levine MA, Jap TS, Mauseth RS, Downs RW, Spiegel AM (1986) Activity of the stimulatory guanine nucleotide-binding protein is reduced in erythrocytes from patients with pseudohypoparathyroidism and pseudopseudohypoparathyroidism: biochemical, endocrine, and genetic analysis of Albright's hereditory osteodystrophy in six kindreds. J Clin Endocrinol Metab 62: 497-502.

27. Patten JL, Johns DR, Valle D, Eil C, Gruppuso PA, Steele G, Smallwood PM, Levine MA (1990) Mutation in the gene encoding the stimulatory $G$ protein of adenylate cyclase in Albright's hereditary osteodystrophy. N Engl J Med 322: 1412-1419.

28. Weinstein LS, Gejman PV, Friedman E, Kadowaki T, Collins RM, Gershon ES, Spiegel AM (1990) Mutations of the Gs $\alpha$-subunit gene in Albright hereditory osteodystrophy detected by denaturing gradient gel electrophoresis. Proc Natl Acad Sci USA 87: 8287-8290. 